\title{
Diversity of Chromobacterium violaceum isolates from aquatic environments of state of Pará, Brazilian Amazon
}

\author{
LT Dall'Agnol, RN Martins', ACR Vallinoto', KTS Ribeiro/ ${ }^{+}$ \\ Laboratório de Microbiologia e Imunologia, 'Laboratório de Virologia, Instituto de Ciências Biológicas, \\ Universidade Federal do Pará, Rua Augusto Corrêa 01, 66075-110 Belém, PA, Brazil
}

The present study intended to characterize the phenotypic and genetic diversity of Brazilian isolates of Chromobacterium violaceum from aquatic environments within the Amazon region. Nineteen isolates showed morphological properties of $\mathrm{C}$. violaceum and the majority grew at $44^{\circ} \mathrm{C}$. Low temperatures, in contrast, showed to be inhibitory to their growth, as eleven isolates did not grow at $10^{\circ} \mathrm{C}$ and nine did not produce pigmentation, clearly indicating an inhibition of their metabolism. The largest variation among isolates was observed in the citrate test (Simmons), in which 12 isolates were positive, and in the oxidation/fermentation of sucrose, with six positives isolates. Chloramphenicol, gentamicin and sulfonamides efficiently inhibited bacterial growth. Amplified products of the recA gene were digested with HindII or PstI, which produced three or four restriction fragments patterns, respectively. The combined analysis arranged the isolates into six genospecies. The higher diversity observed in Belém (genotypes $C, D, E$ and $F$ ) may be a consequence of intense human occupation, pollution of the aquatic environment or due to the higher diversity of the environments sampled in that region. In conclusion, a high level of genetic and phenotypic diversity was observed, and four new genospecies were described.

Key words: Chromobacterium violaceum - Recombinase A - RFLP - diversity - Amazon region

Chromobacterium violaceum was first described by Bergonzini in 1880 (Sneath 1984) and belongs to the family Neisseriacea of $\beta$-Proteobacteria. It is a Gramnegative, heterotrophic, flagellated, free-living organism which lives in a variety of ecosystems in tropical and subtropical regions, including the soil and water of the Amazon region (Hungria et al. 2004). The main feature of this microorganism is the production of a purple pigment named violacein (Antônio \& Creczynski-Pasa 2004, Dessaux et al. 2004), although non-pigmented strains have also been reported (Sivendra \& Tan 1977).

Violacein possesses anti-leishimanial (Leon et al. 2001), anti-viral (Andrighetti-Fröhmer et al. 2003), antitumoral (Ueda et al. 1994, Melo et al. 2000) and anti-Mycobacterium tuberculosis (de Souza et al. 1999) activities. Other properties of $C$. violaceum include the production of cyanide (Michaels \& Corpe 1965), the solubilization of gold (Faramarzi et al. 2004), the production of chitinolytic enzymes (Chernin et al. 1998), the synthesis of bioplastics (Steinbüchel et al. 1993) and environmental detoxification (Carepo et al. 2004). Although it is a valuable biotechnological resource, $C$. violaceum is a highly virulent opportunistic pathogen to humans and animals (Chen et al. 2003, Brito et al. 2004, Dias et al. 2005, de Siqueira et al. 2005).

Financial support: CNPq, Programa de Pós-Graduação Biologia de Agentes Infecciosos e Parasitários/UFPA

+Corresponding author: karlarib@ufpa.br

Received 16 May 2008

Accepted 26 September 2008
The genome of $C$. violaceum, strain ATCC 12472, was sequenced by the Brazilian National Genome Project Consortium (de Vasconcelos et al. 2003), but few studies have investigated the diversity of indigenous isolates in Brazil or in the Amazon region (Hungria et al. 2005, Lima-Bittencourt et al. 2007).

Recombinase A (RecA) is a multifunctional protein involved in general recombination, DNA repair and the SOS response, and it is highly conserved among eubacteria (Cox 2003). Several studies have shown that recA can be used as a molecular tool to study diversity within the Erwinia genus (Waleron et al. 2002), C. violaceum (Scholz et al. 2005), Ochrobactrum anthropi (Scholz et al. 2006) and the Burkholderia cepacia complex (Seo \& Tsuchiya 2004), despite this gene's high degree of nucleotide diversity (Casati et al. 2004).

The present study aims to further characterize the phenotypic and genetic diversity of Brazilian isolates of $C$. violaceum from aquatic environments within the Amazon region.

\section{MATERIALS AND METHODS}

Isolates from natural water resources and reference strain - Water samples were collected from domestic wells (less than $15 \mathrm{~m}$ in depth) in Barcarena (site 1) and in Vila Bonifácio, municipality of Bragança (site 2). Samples were also collected from rivers within the National Forest of Caxiuana (site 3) and in Belém, the capital of Pará (site 4).

Nineteen isolates of $C$. violaceum were recovered from superficial and underground water using the Membrane Filter (MF) and Most Probable Number (MPN) technique, according to the Standard Methods for the Examination of Water and Wastewater (APHA 2005). The MF technique was performed by the filtra- 
tion of water samples through a sterile cellulose ester membrane with $0.45 \mu \mathrm{m}$ pores. Membranes were transferred to m-Endo-type media with incubation at $37^{\circ} \mathrm{C}$ for $24 \mathrm{~h}$. The MPN technique consisted of the inoculation of sequential volumes of water samples in Lactose Broth, followed by incubation at $37^{\circ} \mathrm{C}$ for $24-48 \mathrm{~h}$. The colonies that presented a violet pigmentation in the isolation medium were transferred to Agar Stock (storage medium). Prior to biochemical or molecular testing, isolates were grown in Nutrient Broth (NB) for $24 \mathrm{~h}$ at $37^{\circ} \mathrm{C}$ and placed in Nutrient Agar to re-isolate and confirm the anoxic condition of the culture. The reference strain ATCC 12472 was obtained from the Brazilian Collection of Industrial and Environmental Microorganism.

Phenotypic characterization - Isolates were transferred to NB and incubated at $10,37,40$ and $44^{\circ} \mathrm{C}$ for 24-48 h. Cultures positive at $37^{\circ} \mathrm{C}$ were inoculated to test growth ability and pigment production. Each isolate was also inoculated in triple sugar iron agar and from this inoculated to indole, methyl red, citrate (Simmons), lysine iron agar, catalase, motility, nitrate and oxidation/ fermentation of sucrose, dextrose and lactose.

Susceptibility to antimicrobials - The susceptibility test was performed in Mueller-Hinton agar using the Kirby-Bauer disc diffusion method, according to Bauer et al. (1966). The antimicrobials tested were cefoxitin $(30 \mu \mathrm{g})$, chloramphenicol $(30 \mu \mathrm{g})$, gentamicin $(10 \mu \mathrm{g})$, penicillin $(10 \mathrm{U})$ and sulfonamides $(300 \mu \mathrm{g})$. The results were determined by measuring the inhibition of the growth halo and comparing with the standard values established by the Clinical and Laboratory Standard Institute Manual (NCCLS 2003).

DNA extraction - Genomic DNA was extracted from bacterial culture after incubation for $48 \mathrm{~h}$ in $\mathrm{NB}$ at $35^{\circ} \mathrm{C}$ using the SDS/proteinase $\mathrm{K}$ based method described by Ausubel et al. (2003), with the addition of 5\% RNAse for $1 \mathrm{~h}$ at $55^{\circ} \mathrm{C}$ (within the proteinase $\mathrm{K}$ ).

RecA amplification PCR - The primer pair recA-viol-f' (5' -AAGACAAGAGCAAGGCGCTGGC-3') and recA-viol-r (5' -TCGAAGGCGTCGTCGGCGAAC-3') (Scholz et al. 2005) generated a 1040 bp fragment. PCR was performed in an Eppendorf Mastercycler Personal thermocycler in a $50 \mu \mathrm{L}$ mix with $10 \rho \mathrm{mol}$ of each primer and a program of an initial cycle of denaturation at $94^{\circ} \mathrm{C}$ for $3 \mathrm{~min} ; 30$ cycles of denaturation at $94^{\circ} \mathrm{C}$ for $30 \mathrm{~s}$, annealing at $67^{\circ} \mathrm{C}$ for $30 \mathrm{~s}$ and elongation at $72^{\circ} \mathrm{C}$ for $90 \mathrm{~s}$; a final extension cycle at $72^{\circ} \mathrm{C}$ and a final soak at $4^{\circ} \mathrm{C}$ for 5 min completed the run. Each PCR product $(10 \mu \mathrm{L})$ were visualized in a $0.8 \%$ (in TAE buffer) agarose gel eletrophoresis after staining with ethidium bromide.

RecA RFLP analysis - Each PCR product was digested in separate reactions with the two restriction endonucleases PstI (Invitrogen, USA) and HindII (Sigma, USA). Digestion was performed in a mix of $50 \mu \mathrm{L}$ with $5 \mathrm{U}$ of each enzyme and $15 \mu \mathrm{L}$ of each PCR product for $2 \mathrm{~h}$, using the conditions recommended by the manufacturer. Restriction fragments were separated in a $10 \%$ polyacryl- amide gel electrophoresis and documented by photography following silver and sodium hydroxide staining.

Dendrogram construction - The enzymatic digestion results were analyzed with the Network 4.5 software (http://www.fluxus-engineering.com/sharepub.htm\#a1), using the median joining algorithm (Bandelt et al. 1999) to construct a dendrogram of the relationship between isolates and the reference strain.

\section{RESULTS}

Phenotype characterization - Nineteen isolates and the reference strain were characterized according to their pigment production at $37^{\circ} \mathrm{C}$ and their ability to grow at temperatures ranging from $10-44^{\circ} \mathrm{C}$ (Table I). All the isolates showed morphological properties of $C$. violaceum (Sneath 1984). Strains CV6, CV29 and CV83 lost the ability to produce pigmentation during storage and CV83, CV96, CV115 and CV117 were motility negative. Biochemical identification was confirmed by the amplification of the fragment of $r e c A$ gene.

All C. violaceum strains studied displayed similar properties in our biochemical characterization (Table II), with the exception of strains CV96 (positive in the indole and methyl red tests), CV5 and CV18 (positive in the lysine test). The largest variation was observed in the citrate test (Simmons), in which 12 isolates were positive, and in the oxidation/fermentation of sucrose, with six positives isolates.

\section{TABLE I}

Characteristics of Chromobacterium violaceum isolates, according to the site of water collection, pigment production and temperature of growth

\begin{tabular}{|c|c|c|c|c|c|c|}
\hline \multirow[b]{2}{*}{ Isolate } & \multirow[b]{2}{*}{ Site } & \multirow[b]{2}{*}{ Pigmentation } & \multicolumn{4}{|c|}{ Growth $\left({ }^{\circ} \mathrm{C}\right)$} \\
\hline & & & 10 & 37 & 40 & 44 \\
\hline $\mathrm{CV} 5$ & S1 & + & + & + & + & + \\
\hline CV6 & S1 & - & + & + & + & + \\
\hline CV7 & S1 & + & + & + & + & + \\
\hline CV8 & S1 & + & + & + & + & + \\
\hline CV10 & S1 & + & + & + & + & + \\
\hline CV12 & S1 & + & + & + & + & + \\
\hline CV18 & $\mathrm{S} 2$ & + & + & + & + & + \\
\hline CV29 & $\mathrm{S} 2$ & - & - & + & + & + \\
\hline CV30 & $\mathrm{S} 2$ & + & - & + & + & + \\
\hline CV83 & $\mathrm{S} 4$ & - & - & + & - & - \\
\hline CV90 & $\mathrm{S} 3$ & + & - & + & + & + \\
\hline CV91 & $\mathrm{S} 3$ & + & - & + & + & + \\
\hline CV96 & $\mathrm{S} 3$ & + & - & + & + & + \\
\hline CV115 & $\mathrm{S} 4$ & + & + & + & + & + \\
\hline CV117 & S4 & + & + & + & + & + \\
\hline CV138 & $\mathrm{S} 4$ & + & - & + & - & - \\
\hline CV140 & S4 & + & - & + & + & + \\
\hline CV142 & $\mathrm{S} 4$ & + & - & + & - & - \\
\hline CV143 & $\mathrm{S} 4$ & + & - & + & - & - \\
\hline ATCC $12472^{a}$ & & + & - & + & + & + \\
\hline
\end{tabular}

$a$ : reference strain; S1: Barcarena; S2: Bragança; S3: Caxiuanã Forest; S4 Belém. 
TABLE II

Phenotypic characterization of Chromobacterium violaceum isolates according to the biochemical tests

\begin{tabular}{|c|c|c|c|c|c|c|c|c|c|c|c|}
\hline Strain & TSI & $\mathrm{CS}$ & Indole & MR & Mot & LIA & Cat & Nit & Suc & Dex & $\mathrm{Lac}$ \\
\hline CV 5 & $\mathrm{~A} / \mathrm{A}$ & - & - & - & + & + & + & + & + & + & - \\
\hline CV 6 & $\mathrm{~K} / \mathrm{A}$ & + & - & - & + & - & + & + & - & + & - \\
\hline $\mathrm{CV} 7$ & $\mathrm{~A} / \mathrm{A}$ & + & - & - & + & - & + & + & + & + & - \\
\hline CV 8 & $\mathrm{~A} / \mathrm{A}$ & + & - & - & + & - & + & + & + & + & - \\
\hline CV 10 & $\mathrm{~K} / \mathrm{A}$ & - & - & - & + & - & + & + & - & + & - \\
\hline CV 12 & $\mathrm{~K} / \mathrm{A}$ & + & - & - & + & - & + & + & - & + & - \\
\hline CV 18 & $\mathrm{~K} / \mathrm{A}$ & - & - & - & + & + & + & + & - & + & - \\
\hline CV 29 & $\mathrm{~K} / \mathrm{A}$ & + & - & - & + & - & + & + & - & + & - \\
\hline CV 30 & $\mathrm{~A} / \mathrm{A}$ & - & - & - & + & - & + & + & - & + & - \\
\hline CV 83 & $\mathrm{~A} / \mathrm{A}$ & + & - & - & - & - & + & + & - & + & - \\
\hline CV 90 & $\mathrm{~A} / \mathrm{A}$ & - & - & - & + & - & + & + & + & + & - \\
\hline CV 91 & $\mathrm{~A} / \mathrm{A}$ & - & - & - & + & - & + & + & + & + & - \\
\hline CV 96 & $\mathrm{~A} / \mathrm{A}$ & + & + & + & - & - & + & + & + & + & - \\
\hline CV115 & $\mathrm{A} / \mathrm{A}$ & + & - & - & - & - & + & + & - & + & - \\
\hline CV117 & $\mathrm{A} / \mathrm{A}$ & + & - & - & - & - & + & + & - & + & - \\
\hline CV 138 & $\mathrm{~K} / \mathrm{A}$ & + & - & - & + & - & + & + & - & + & - \\
\hline CV 140 & $\mathrm{~K} / \mathrm{A}$ & - & - & - & + & - & + & + & - & + & - \\
\hline CV 142 & $\mathrm{~K} / \mathrm{A}$ & + & - & - & + & - & + & + & - & + & - \\
\hline CV 143 & $\mathrm{~K} / \mathrm{A}$ & + & - & - & + & - & + & + & - & + & - \\
\hline ATCC 12472 & $\mathrm{~A} / \mathrm{A}$ & - & - & - & + & - & + & + & - & + & - \\
\hline
\end{tabular}

A: acid; Cat: catalase; CS: citrate (Simmons); Dex: dextrose; K: alkalyne; Lac: lactose; LIA: lysine iron agar; Mot: motility; MR: methyl red; Nit: nitrate; Suc: sucrose; TSI: triple sugar iron.

Susceptibility to antimicrobials - Chloramphenicol, gentamicin and sulfonamides were sufficient to inhibit the growth of both the isolates and the reference strain. CV140 was only partially inhibited by gentamicin and CV83 was the sole isolate inhibited by cefoxitin. All isolates were resistant to penicillin.

RecA amplification and RFLP analysis - The amplification of $r e c A$ generated a fragment of $1,040 \mathrm{bp}$ (from the $r e c A$ gene of $1,057 \mathrm{bp}$ ). Amplified products were digested with HindII or PstI, which produced three or four restriction fragments patterns, respectively. The isolates were arranged into six genospecies (Figs 1, 2, Table III). Isolates with no mutation in any restriction site (RS) of the two enzymes were classified into group A. Those isolates with at least one mutation in the Pst I RS but none in HindII were placed into group B. Alter-

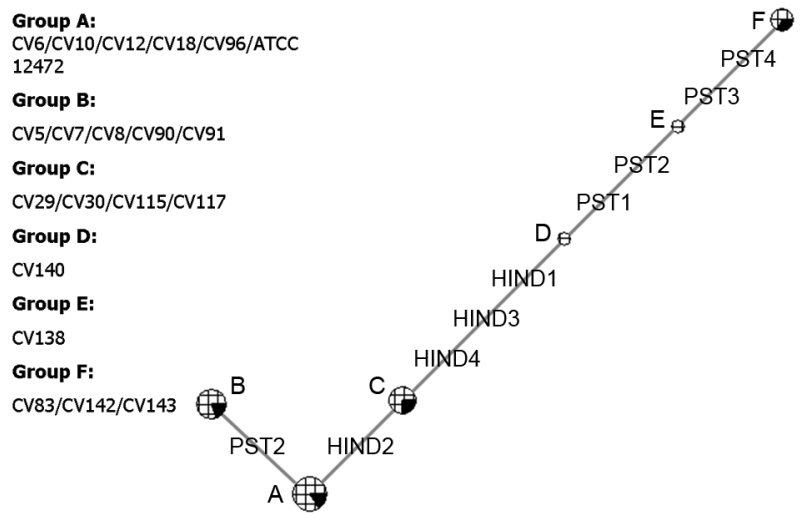

Fig. 2: dendrogram of Chromobacterium isolates from state of Pará and of Chromobacterium violaceum ATCC 12472 based on clustering of $\operatorname{rec} A$ RFLP profile, using the Median Joining algorithm.
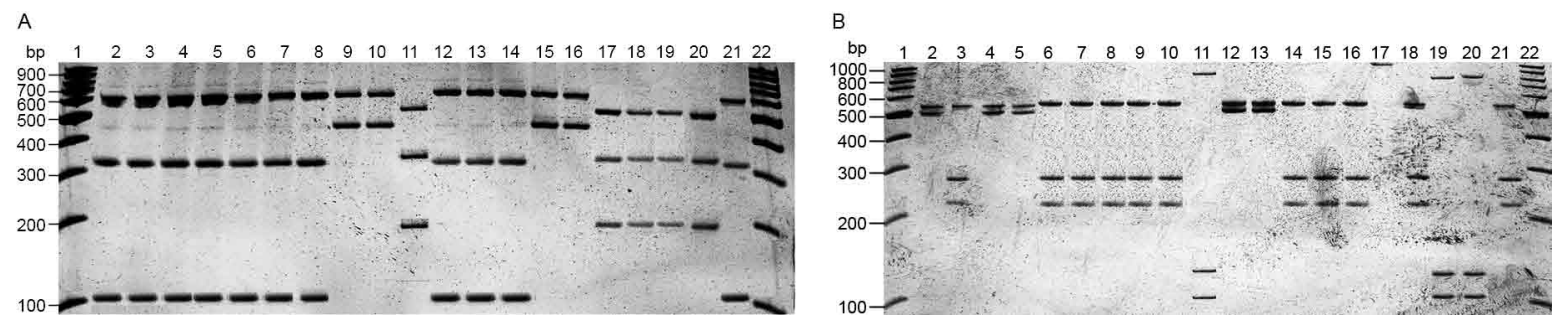

Fig. 1: A: HindII restriction profile of recA PCR product; B: PstI restriction profile of recA PCR product; Lane 1: DNA size standard; 2: CV5; 3: CV6; 4: CV7; 5: CV8; 6: CV10; 7: CV12; 8: CV18; 9: CV29; 10: CV30; 11: CV 83; 12: CV90; 13: CV91; 14: CV96; 15: CV115; 16: CV117; 17: CV138; 18: CV140; 19: CV142; 20: CV143; 21: ATCC 12472; 22: DNA size standard. 
TABLE III

RFLP patterns of the HindII and PstI endonucleases

\begin{tabular}{lccc}
\hline Site & Isolate & RFLP Group & $\begin{array}{c}\text { Minimum number } \\
\text { of }^{\text {mutations }}{ }^{a}\end{array}$ \\
\hline Reference & & & \\
strain & ATCC 12472 & A & 0 \\
S1 & CV5 & B & 1 \\
& CV6 & A & 0 \\
& CV7 & B & 1 \\
& CV8 & B & 1 \\
& CV10 & A & 0 \\
S2 & CV12 & A & 0 \\
& CV18 & A & 0 \\
S3 & CV29 & C & 1 \\
& CV30 & C & 1 \\
& CV90 & B & 1 \\
S4 & CV91 & B & 1 \\
& CV96 & A & 0 \\
& CV83 & F & 8 \\
& CV115 & C & 1 \\
& CV117 & C & 1 \\
& CV138 & E & 6 \\
& CV140 & D & 4 \\
& CV142 & F & 8 \\
& CV143 & F & 8 \\
\hline
\end{tabular}

$a$ : in comparison to the restriction profile of the reference strain.

natively, those that had at least one mutation in the Hin$d$ II RS and none in PstI were placed into group C. The single isolate with no mutation in the PstI RS but four mutations in HindII was placed in group D. Group E was composed by the isolate that had at least four mutations in RS of HindII and at least two in PstI. Finally, group $\mathrm{F}$ consisted of those isolates that had at least four mutations in the RS of both HindII and PstI.

\section{DISCUSSION}

C. violaceum is a saprophitic organism that usually grows at a maximum temperature of $40^{\circ} \mathrm{C}$ (Hungria et al. 2005); however, the majority of indigenous isolates are able to grow at $44^{\circ} \mathrm{C}$, which was seen with the isolates examined in this study. This result is probably related to the high temperatures of the region from which these organisms were isolated (Hungria et al. 2005). One particularly interesting observation from this study was that four isolates from site 4 exhibited reduced growth rates in temperatures above $37^{\circ} \mathrm{C}$. Such a growth defect could be a consequence of the longer duration of storage of those isolates. Although the minimum temperature allowing growth of the species is usually between $10-15^{\circ} \mathrm{C}$ (Sneath 1984), other isolates of the region (Hungria et al. 2005 ) showed no growth under $15^{\circ} \mathrm{C}$. On the other hand, 11 isolates exhibited growth after incubation at $10^{\circ} \mathrm{C}$ and none of them produced pigment under these conditions. It is possible that low temperatures are more restrictive to $C$. violaceum and that the production of violacein is not essential for the survival of the bacteria (Efthimion \& Corpe 1969).
A larger phenotypic variation was observed under the citrate test and the oxidation/fermentation of sucrose, which reflects the diversity of metabolic pathways to obtain nutrients from the environment. The biochemical results indicate the great environmental adaptability and tolerance to stress of $C$. violaceum (Creczynski-Pasa \& Antônio 2004, Hungria et al. 2004).

Human infections of $C$. violaceum are uncommon and of different clinical and laboratory diagnosis (Scholz et al. 2005). The typical infection occurs as a short-duration, highly virulent disease; therefore, the need for a rapid diagnosis and susceptibility profile to antimicrobials is urgent (Dias et al. 2005). When compared to in vitro data, the results obtained with the antimicrobials sensitivity test are very similar to those observed in other studies (Lee et al. 1999). In silico studies of the genome (Fantinatti-Garboggini et al. 2004) detected a probable gene of chloramphenicol resistance; however, resistance to this antibiotic was not observed in vitro.

The primers used in the present study were sufficient to biochemically identify the recA gene through PCR amplification of a 1,040 bp fragment. RFLP analysis was previously described as a useful genetic marker to indicate bacterial variability both within and among species (Waleron et al. 2002, Casati et al. 2004, Seo \& Tsuchiya 2004, Scholz et al. 2006).

Genotype A was described in most of the sites sampled (1, 2 and 3). Site 3 is a National Florest reserve, which is supposedly not influenced by the presence of humans. The higher diversity observed in Belém (genotypes $\mathrm{C}$, $\mathrm{D}, \mathrm{E}$ and F) may be a consequence of intense human occupation, pollution of the aquatic environment or possibly a reflection of the higher diversity of environments sampled. A similar degree of diversity was observed in isolates from the state of Amazonas (Hungria et al. 2005) which suggests that high diversity is an intrinsic characteristic of the species found within the Amazon region. The present study showed one new restriction profile for the HindII enzyme and three for PstI. Previously described strains with one restriction profile in HindII and two in Pst I were absent (Scholz et al. 2005).

These results demonstrate the great variability, both phenotypic and genetic, of the species in the Amazonian aquatic environment, and therefore they are important for a better understanding of $C$. violaceum adaptability. Furthermore, this report may form a basis for further studies exploring all the potentialities that this bacterium offers.

\section{ACKNOWLEDGMENTS}

To the Laboratório de Polimorfismo de DNA/UFPA, for material support, especially to Rafael Silva Rocha and Ricardo Souza, and to Professor Ricardo Ishak, for reviewing the manuscript.

\section{REFERENCES}

Andrighetti-Fröhner CR, Antonio RV, Creczynski-Pasa TB, Barardi CRM, Simões CMO 2003. Cytotoxicity and potential antiviral evaluation of violacein produced by Chromobacterium violaceum. Mem Inst Oswaldo Cruz 98: 843-848.

Antonio RV, Creczynski-Pasa TB 2004. Genetic analysis of violacein biosynthesis by Chromobacterium violaceum. Genet $\mathrm{Mol}$ Res 3: 85-91. 
APHA - American Public Health Association 2005. Standard methods for the examination of water and wastewater, 21st ed., APHA, AWWA, APCF, Washington, 1368 pp.

Ausubel FM, Brent R, Kingston RF, Moore DD, Seidman JG, Smith JA, Struhl K 2003. Current protocols in molecular biology, Greene Publishing, New York, 5300 pp.

Bandelt HJ, Forster P, Röhl A 1999. Median-joining networks for inferring intraspecific phylogenies. Mol Biol Evol 16: 37-48.

Bauer AW, Kirby WM, Sherris JC, Turck M 1966. Antibiotic susceptibility testing by a standardized single disk method. Am J Clin Pathol 45: 493-496.

Brazillian National Genome Project Consortium 2003. The complete genome sequence of Chromobacterium violaceum reveals remarkable and exploitable bacterial adaptability. Proc Natl Acad Sci USA 100: 11660-11665.

Brito CFA, Carvalho CMB, Santos FR, Gazzinelli RT, Oliveira SC, Azevedo V, Teixeira SMR 2004. Chromobacterium violaceum genome: molecular mechanisms associated with pathogenicity. Genet Mol Res 3: 148-161.

Carepo MSP, Azevedo JSN, Porto JIR, Bentes-Souza AR, Batista, JS, Silva ALC, Schneider MPC 2004. Identification of Chromobacterium violaceum genes with potential biotechnological application in environmental detoxification. Genet Mol Res 3: 181-194.

Casati S, Bernasconi MV, Gern L, Piffaretti JC 2004. Diversity within Borrelia burgdorferi sensu lato genospecies in Switzerland by recA gene sequence. FEMS Microbiol Lett 238: 115-123.

Chen CH, Lin LC, Liu CE, Young TZ 2003. Chromobacterium violaceum bacteremia: a case report. J Microbiol Immunol Infect 36: 141-144.

Chernin LS, Winson MK, Thompson JM, Haran S, Bycroft BW, Chet I, Williams P, Stewart GSAB 1998. Chitinolytic activity in Chromobacterium violaceum: substrate analysis and regulation by quorum sensing. J Bacteriol 180: 4435-4441.

Cox MM 2003. The bacterial reca protein as a motor protein. Annu Rev Microbiol 57: 551-557.

Creczynski-Pasa TB, Antônio RV 2004. Energetic metabolism of Chromobacterium violaceum. Genet Mol Res 3: 162-166.

de Siqueira IC, Dias J, Ruf H, Ramos EAG, Maciel EAP, Rolim A, Jabur L, Vasconcelos L, Silvany C 2005. Chromobacterium violaceum in Siblings, Brazil. Emerg Infect Dis 11: 1443-1445.

de Souza AO, Aily DCG, Sato DN, Durán N 1999. Atividade da violaceína in vitro sobre o Mycobacterium turbeculosis H37RA. Rev Inst Adolfo Lutz 58: 59-62.

Dessaux Y, Elmerich C, Faure D 2004. Violacein: a molecule of biological interest originating from the soil-borne bacterium Chromobacterium violaceum. Rev Med Interne 25: 659-662.

Dias JP, Silvany C, Saraiva MM, Ruf HR, Guzmán JD, Carmo EH 2005. Chromobacteriosis in Ilhéus, Bahia: epidemiologic, clinical and laboratorial investigation. Rev Soc Bras Med Trop 38: 503-506.

Efthimion MH, Corpe WA 1969. Effect of cold temperatures on the viability of Chromobacterium violaceum. Appl Microbiol 17: 169-175.

Fantinatti-Garboggini F, Almeida R, Portillo VA, Barbosa TAP, Trevilato PB, Neto CER, Coêlho RD, Silva DW, Bartoleti LA, Hanna ES, Brocchi M, Manfio GP 2004. Drug resistance in Chromobacte-rium violaceum. Genet Mol Res 3: 134-147.
Faramarzi MA, Stagars M, Pensini E, Krebs W, Brandl H 2004. Metal solubilization from metal-containing solid materials by cyanogenic Chromobacterium violaceum. J Biotechnol 113: 321-326.

Hungria M, Astolfi-Filho S, Chueire LMO, Nicolás MF, Santos EBP, Bulbol MR, Souza-Filho A, Assunção EN, Germano MG, Vasconcelos ATR 2005. Genetic characterization of Chromobacterium isolates from black water enviroments in the Brazilian Amazon. Lett Appl Microbiol 41: 17-23.

Hungria M, Nicolás MF, Guimarães CT, Vasconcelos ATR 2004. Tolerance to stresses and environmental adaptability of Chromobacterium violaceum. Genet Mol Res 3: 102-116.

Lee J, Kim JS, Nahm CH, Choi JW, Kim J, Pai SH, Moon KH, Lee $\mathrm{K}$, Chong Y 1999. Two cases of Chromobacterium violaceum infection after injury in a subtropical region. J Clin Microbiol 37: 2068-2070.

Leon LL, Miranda CC, de Souza AO, Durán N 2001. Antileishmanial activity of the violacein extracted from Chromobacterium violaceum. J Antimicrob Chemother 48: 449-450.

Lima-Bittencourt CI, Astolfi-Filho S, Chartone-Souza E, Santos FR, Nascimento AMA 2007. Analysis of Chromobacterium sp. natural isolates from different Brazilian ecosystems. $B M C M i$ crobiol 7: 1-9.

Melo PS, Maria SS, Vidal BC, Haun M, Durán N 2000. Violacein cytotoxicity and induction of apoptosis in V79 cells. In Vitro Cell Dev Biol Anim 36: 539-543.

Michaels R, Corpe WA 1965. Cyanide formation by Chromobacterium violaceum. J Bacteriol 89: 106-112.

NCCLS - National Commitee For Clinical Laboratory Standards 2003. Performance Standards for Antimicrobial Disk Susceptibility Tests; Approved Standard, document M2-A8, 8th ed., NCCLS, Wayne, $58 \mathrm{pp}$.

Scholz HC, Witte A, Tomaso H, Dahouk SA, Neubauer H 2005. Genotyping of Chromobacterium violaceum isolates by recA PCR-RFLP analysis. FEMS Microbiol Lett 244: 347-352.

Scholz HC, Witte A, Tomaso H, Dahouk SA, Neubauer H 2006. Genotyping of Ochrobactrum anthropi by recA-based comparative sequence, PCR-RFLP, and 16S rRNA gene analysis. FEMS Microbiol Lett 257: 7-16.

Seo ST, Tsuchiya K 2004. PCR-based identification and characterization of Burkholderia cepacia complex bacteria from clinical and environmental sources. Lett Appl Microbiol 39: 413-419.

Sivendra R, Tan SH 1977. Pathogenicity of nonpigmented cultures of Chromobacterium violaceum. J Clin Microbiol 5: 514-516.

Sneath PHA 1984. Genus Chromobacterium Bergonzini 1881, 153AL, In NH Krieg, JG Holt eds., Bergey's Manual of Systematic Bacteriology, Vol. 1, Williams \& Wilkins, Baltimore, p. 580-582.

Steinbüchel A, Debzi EM, Marchessault RH, Timm A 1993. Synthesis and production of poly (3-hydroxyvaleric acid) homopolyester by Chromobacterium violaceum. Appl Microbiol Biotechnol 39: 443-449.

Ueda H, Nakajima H, Hori Y, Goto T, Okuhara M 1994. FR901228, a novel antitumor bicyclic depsipeptide produced by Chromobacterium violaceum $\mathrm{n}^{\circ}$. 968. I. Taxonomy, fermentation, isolation, physico-chemical and biological properties. J Antibiot (Tokio) 47: 301-310.

Waleron M, Waleron K, Podhajska AJ, Łojkowska E 2002. Genotyping of bacteria belonging to the former Erwinia genus by PCR-RFLP analysis of a recA gene fragment. Microbiology 148: 583-559. 